\title{
REAL OPTIONS ANALYSIS OF RENEWABLE ENERGY INVESTMENT SCENARIOS IN THE PHILIPPINES
}

\author{
Casper Agaton \\ Institute of Development Research and Development Policy, Ruhr University of Bochum, Germany
}

Casper.Agaton@rub.de

\begin{abstract}
With the continuously rising energy demand and much dependence on imported fossil fuels, the Philippines is developing more sustainable sources of energy. Renewable energy seems to be a better alternative solution to meet the country's energy supply and security concerns. Despite its huge potential, investment in renewable energy sources is challenged with competitive prices of fossil fuels, high start-up cost and lower feed-in tariff rates for renewables. To address these problems, this study aims to analyze energy investment scenarios in the Philippines using real options approach. This compares the attractiveness of investing in renewable energy over continuing to use coal for electricity generation under uncertainties in coal prices, investments cost, electricity prices, growth of investment in renewables, and imposing carbon tax for using fossil fuels.
\end{abstract}

Keywords - real options approach, investment under uncertainty, dynamic optimization, renewable energy.

\section{NOMENCLATURE}

$\begin{array}{ll}\text { ADF } & \text { Augmented Dickey-Fuller } \\ \text { BAU } & \text { business as usual } \\ \text { DCF } & \text { discounted cash flow } \\ \text { FiT } & \text { feed-in tariff } \\ \text { GBM } & \text { geometric Brownian motion } \\ \text { IRENA } & \text { International Renewable Energy Agency } \\ \text { NPV } & \text { net present value } \\ \text { O\&M } & \text { operations and maintenance } \\ \text { PV } & \text { photovoltaic } \\ \text { RES } & \text { renewable energy resources } \\ \text { ROA } & \text { real options approach }\end{array}$

\section{INTRODUCTION}

Increasing environmental concerns and depleting fossil fuels have caused many countries to find cleaner and more sustainable sources of energy. Currently, renewable energy sources (RES) supply $12.65 \%$ of the total world energy demand in 2016 which includes wind, solar, hydropower, biomass, geothermal, and ocean energies [1]. In the recent years, new investments in renewable energy have grown from US $\$ 1043.8 \mathrm{~B}$ (2007-2011) to US $\$ 1321.9$ (2012-2016) with a geographic shift from the AsiaPacific region [2], [3]. In the Philippines, renewable energy accounts to $25 \%$ of the energy generation mix, mostly from geothermal (13\%) and hydropower $(10 \%)$ [4]. The country is aiming to increase this percent share to $60 \%$ in 2030 by investing and developing localized renewable sources at $4 \%$ annual growth rate [5]. According to International Renewable Energy Agency (IRENA), the country's topography and geographic location makes a good potential for renewable energy with $170 \mathrm{GW}$ from ocean, $76.6 \mathrm{GW}$ from wind, 4GW from geothermal, 500MW from biomass, and $5 \mathrm{kWh} / \mathrm{m} 2 /$ day from solar energy [6]. Despite its potential, the country's $60 \%$ renewable energy goal seems unachievable as the growth in electricity demand increases faster than investment and generation from RES. Meanwhile, the country is burdened by heavy dependence on imported fossil fuels, particularly coal and oil. As more power plants are needed due to closing old coal plants and rising electricity demand, renewable energy seems to be the long-term solution to address the country's problem on energy security and sustainability. However, investment in renewable energy sources is challenged by competitive prices of fossil fuels, high investment cost and lower feed-in tariff (FiT) rates for renewables. These serve as an impetus to evaluate the comparative attractiveness of renewable energy over coal for electricity generation in the Philippines.

This study presents a general framework of investment decision-making for shifting technologies from coal to renewable sources that can be applied to developing countries. By taking the case of the Philippines, this study applies the real options approach (ROA) to analyze various investment scenarios. Traditionally, the discounted cash flow (DCF) or net present value (NPV) techniques are mostly used in evaluating investment projects. These 
methods, however, do not cover highly volatile and uncertain investments because they assume a definite cash flow. This assumption makes DCF and NPV underestimate the investment opportunities leading to poor policy and decision-making process, particularly to energy generation projects. Further, these approaches do not allow an investor to define the optimal time to invest or to estimate the true value of project uncertainties [7]. ROA overcomes this limitation as it combines risk and uncertainty with flexibility of investment as a potential positive factor, which gives additional value to the project [8]. This approach evaluates investment projects by considering the investor's flexibility to delay or postpone his/her decision to a more favorable situation [9]. These ROA characteristics are highlighted in this paper as the decision-making process to invest in RES is evaluated in every investment period (annually) using dynamic optimization under various uncertainties.

Recent studies employ ROA to analyze investment decisions, specifically renewable energy, including: Zhang et al. [10] on investment in solar photovoltaic (PV) power generation in China by considering uncertainties in unit generating capacity, market price of electricity, $\mathrm{CO}_{2}$ price, and subsidy; Kim et al. [11] on analyzing renewable energy investment in Indonesia with uncertainties in tariff, energy production, Certified Emission Reduction price, and operations and maintenance (O\&M) cost; Kitzing et al. [12] on analyzing offshore wind energy investments in the Baltic under different support schemes as FiT, feed-in premiums, and tradable green certificates; Tian et al. [13] on evaluating PV power generation under carbon market linkage in carbon price, electricity price, and subsidy uncertainty; and Ritzenhofen and Spinler [14] on assessing the impact of FiT on renewable energy investments under regulatory uncertainty. This research contributes to existing literatures by presenting a multi-period investment coupled with uncertainties in coal prices, cost of renewable technologies, growth of renewable energy investment, FiT price of renewables, and externality for using coal.

The main goal of this paper is to analyze investment scenarios that make renewable energy a better option than continuing to use coal for electricity generation. Specifically, this study employs ROA to evaluate the (1) maximized option value of either continuing to use coal or investing in renewables, (2) value of waiting or delaying to invest in renewables, and (3) optimal timing of investment characterized by the trigger price of coal for shifting technologies from coal to renewables. Sensitivity analyses are done to investigate how the above-mentioned uncertainties affect the optimal investment strategies.

\section{METHODOLOGY}

The proposed real options methodology is divided into two subsections. The first subsection describes dynamic optimization to calculate the maximized value of investment and identify the optimal timing of investment. The second stage includes the sensitivity analyses with respect to growth rate of renewable energy investment, prices of renewable energy, investment costs, and $\mathrm{CO}_{2}$ prices.

\section{- Real options model}

Consider a renewable energy project with lifetime $T_{R}$, which can be irreversibly initiated in three installment periods $\tau, \tau+5$, and $\tau+10$ with investment costs $I_{R_{-} 0}, I_{R_{-} 5}$, and $I_{R_{-} 10}$. Assume that the project construction can be finished instantaneously and operated in full load after project completion. If renewable energy project starts in period $\mathrm{t}$, the total net present value of the project $N P V_{R}$ can be represented by Equation 1 .

$N P V_{R}=N P V_{R_{0}}+N P V_{R_{5}}+N P V_{R_{10}}=$
$\sum_{r=0,5,10}\left[\sum_{t=\tau+r}^{T_{R}+r} \rho^{t} P V_{R, t}-\left(1+\varphi_{r}\right) I_{R, r}\right]$

where $r$ is the installment periods of renewable energy investment, $\varphi_{r}$ is the growth of renewable energy investment cost, and $\tau$ is the period where investor decides to invest in renewable.

The yearly cash flow $P V_{R, t}$ of renewable energy project comprises of returns from selling electricity from RE and O\&M cost $C_{R}$.

$P V_{R}=\pi_{R}=P_{E R} Q_{R}-C_{R, r}$

On the other hand, there exists a power plant generated with coal. The net present value of yearly cash flow from coal depends on the returns from selling electricity from coal, O\&M cost $C_{C}$, stochastic 
cost of fuel $P_{C, t}$, and $\mathrm{CO}_{2}$ price $\mathrm{C}_{\mathrm{C}_{-} \mathrm{CO}_{2}}$ as given in Equation 3

$N P V_{C, t}=\sum_{t=0}^{\tau} P V_{C, t}=\sum_{t=0}^{\tau} \rho^{t} \pi_{C, t}=$

$\sum_{t=0}^{\tau} \rho^{t}\left\{P_{E C} Q_{R}-P_{C, t} Q_{C}-C_{C}-C_{C_{-} C O_{2}}\right\}$

where $\rho$ is the social discount factor, $P_{E C}$ and $P_{E R}$ are the prices of electricity from coal and renewable, $Q_{R}$ is the quantity of electricity generated from coal/renewable, and $Q_{C}$ is the quantity of coal needed to generate $Q_{R}$.

Following previous literatures [15]-[19], this research assumes that the price of coal is stochastic and follows Geometric Brownian motion (GBM). The current price of $P_{C}$ depends on its previous price, and the drift and variance rates of time series of coal prices as shown in Equation 4

$P_{C, t}=P_{C, t-1}+\alpha P_{C, t-1}+\sigma P_{C, t-1} \varepsilon_{t-1}$

with $\alpha$ and $\sigma$ are the GBM rate of drift and variance of coal prices, and $\varepsilon$ a random number.

The parameters $\alpha$ and $\sigma$ are approximated using augmented Dickey-Fuller (ADF) test from time series of coal prices [20]. The estimates obtained in ADF test are used to generate a matrix of random numbers that represent possible prices of coal from initial values of zero to US $\$ 200$ at every investment period from zero to $T$. These values are then used to calculate the present values of electricity generation from coal for each period.

Using Monte Carlo simulation, the expected NPV for generating electricity from coal is estimated by calculating the $N P V_{C, t}$ in Equation 3 and repeating the process for a sufficiently large number $J=10000$ times. Expected net present value is calculated by taking the average of $N P V_{C}$ for every initial price of coal $P_{C, 0}$ as shown in Equation 5.

$\mathbb{E}\left\{N P V_{C, J} \mid P_{C, 0}\right\} \approx \frac{1}{J} \sum_{j=1}^{J} N P V_{C, J} \approx \mathbb{E}\left\{N P V_{C} \mid P_{C, 0}\right\}$

The next exercise in identifying the optimal timing and associated trigger price of coal for shifting technologies is done with dynamic optimization as shown in Equation 6. $\max _{0 \leq \tau<T+1} \mathbb{E}\left\{\sum_{t=0}^{\tau} \rho^{t} \pi_{C, t}+\sum_{t=\tau}^{T} \rho^{t} \pi_{C, t}\left(1-\mathbb{I}_{\{\tau \leq T\}}\right)+\left[N P V_{R}+\right.\right.$ $\left.\left.N P V_{C}\right]\left(\mathbb{I}_{\{\tau \leq T\}}\right)\right\}$

where $\dot{\mathrm{n}}_{\tau \leq T}$ is an indicator equal to 1 if switching to renewable energy, otherwise, equal to 0 . This model describes an investor who is given a specific period $T$ to decide whether to continue generating electricity from coal or invest in renewable energy. In this model, $\sum_{t=0}^{\tau} \rho^{t} \pi_{C, t}$ accounts to the net present value of using coal from initial period $T=0$ until $T$ when the investor makes the decision. If the investor chooses not to invest $\left(\mathbb{1}_{\tau \leq T}=0\right)$, he/she incurs a net present value of $\sum_{t=\tau}^{T} \rho^{t} \pi_{C, t}$ from period $\mathrm{T}$ until the end of the coal plant's lifetime. If the investor chooses to invest $\left(\mathbb{1}_{\tau \leq T}=1\right)$, he/she incurs a net present value of $N P V_{R}$ from successive (three-period) investment in renewables plus $N P V_{C}$, as generation from coal will continue at a lower quantity because other electricity will be generated from renewables.

From Equation 6, the investor's problem is to choose the optimal timing of investment $\tau$, to maximize the expected net present value of investment. The problem is solved backwards using dynamic programming from the terminal period for each price of coal $P_{c, t}$ as shown in Equation 7

$V_{t}\left(P_{c, t}\right)=\max \left\{\pi_{C, t-1}+V_{t}\left(P_{c, t-1}\right), N P V_{R}+N P V_{C}\right\}$

with $V_{t}$ as the option value of investment at coal price $P_{c, t}$.

The optimal timing of investment $\widetilde{P_{C}}$ is characterized by the minimum price of coal so that switching to renewable energy is optimal as shown in Equation 8 [19], [21].

$\widetilde{P_{C}}=\min \left\{P_{c, t} \mid V_{0}\left(P_{c, t}\right)=V_{\mathrm{T}}\left(P_{c, \mathrm{t}}\right)\right\}$

Finally, investment strategy is described by a decision to invest when $\widetilde{P_{C}} \leq P_{c}$, otherwise, investment can be delayed in later periods until $\widetilde{P_{C}}=P_{c}$. 


\section{- Parameter Estimation and Investment Scenarios}

The following scenarios describe various environments that affect investment decisions in renewable energy in the Philippines. Sensitivity of investment values and optimal timing are analyzed with respect to growth rate of renewable energy investment, price of electricity from renewable energy, investment cost, and carbon prices.

The first scenario is the BAU case which describes the current renewable energy investment scenario in the country. To estimate a suitable set of parameters in this scenario, secondary data from the Philippine's Department of Energy and Energy Information Administration are used [12], [ 22]. A 30-year period of average annual coal prices from 1987-2016 is used to run the ADF test described in Equation 4. The ADF test result (see Supplementary Information Table 2) implies that the null hypothesis that $p_{t}$ has a unit root cannot be rejected at all significant levels, hence, coal prices conform with GBM. From this test, the estimated GBM parameters are $\alpha=0.032027$ and $\sigma=0.249409$, and are used to approximate stochastic prices of coal for each investment period. The social discount rate is set to $7.5 \%$. From Equation 3, $\mathrm{C}_{\mathrm{C}_{-} \mathrm{CO}_{2}}$ is set to zero as there are no existing carbon prices in the Philippines at present. The growth rate of renewable energy investment is set to $2 \%$ per annum. This is equivalent to $470 \mathrm{GWh}$ of electricity generation from renewables. From this value, the investment cost and operations and maintenance cost for renewables are estimated, as well as the costs and quantity of coal needed to generate this amount. The prices of electricity, $P_{E R}=$ $P_{E C}=\mathrm{US} \$ 182.2 / \mathrm{MWh}$ are set equal to the current domestic electricity price, constant during the entire investment period, and independent of the domestic demand. Assumptions indicate that renewable energy sources can generate electricity at an annual average of $Q_{R}$ all throughout its lifetime; there are no technological innovations that affect energy efficiency and overnight costs of renewables; and stochastic prices of coal are independent of the demand for renewable energy.

The second scenario describes a situation of an accelerated growth rate of renewable energy investment from the current $2 \%$ to $4 \%, 6 \%$, and $8 \%$.
Meanwhile, the third scenario analyzes the effect of prices of electricity from renewable energy by increasing the current FiT rates to proposed rates. Three prices are set: US\$182.2/MWh at the BAU case, US $\$ 160 / \mathrm{MWh}$ which is $10 \%$ lower than the BAU case, and US $\$ 200 / \mathrm{MWh}$ which is $10 \%$ higher. The third scenario describes a situation of a decline in investment costs for renewable energies by $5 \%$, $10 \%$, and $15 \%$, respectively. The last scenario proposes a government policy of introducing carbon tax for electricity generation from coal. The carbon tax is set to US\$ 0.504/MWh.

\section{RESULTS AND DISCUSSION}

\section{- Business as usual scenario}

The dynamic optimization process described in the previous section results in three significant values. First is the option value which is equal to the maximized value of either investing in renewables or continuing to use coal. Second is the value of waiting as described by the vertical distance between option value curves: initial period (dotted) and terminal period (bold) of investment. This value approximates the gains of an investor if investment is delayed or postponed to some period. The last estimated value is the optimal timing of investment denoted by the trigger prices of coal for shifting electricity source from coal to renewables. This trigger price is illustrated as the intersection of the two option value curves, and indicates the threshold where the value of waiting is zero and that an investor has no benefit to delay the investment to renewables.

Figure 1 shows the dynamics of option values at different prices of coal in the business as usual scenario. The first point of interest is the positive option values. It indicates that investment in renewable energy incurs positive returns at the current energy situation in the Philippines. This contradicts with the result of Detert and Kotani [19] where the optimization yields negative option values describing a government controlled, operated, and subsidized energy regime. The next point of interest is option value curves sloping downward. This indicates that option values decrease with increasing cost for input fuel. At certain point on the curves, the option values become constant. These are the prices of coal where investment in renewable is a better option than continuing to use coal for electricity generation. The positive values further indicate 
positive $N P V_{R}$ for investing in renewables. In this scenario, the result shows that the trigger price of coal for shifting technologies is US\$129/short ton. This trigger price is higher than the current price of coal US\$93.13/short ton (year 2016), and implies that delaying investment in renewables is a better option. However, at the current coal price, the value of waiting to invest is -US $\$ 105.4$ million. This negative value indicates possible losses incurred from delaying investment in renewables.

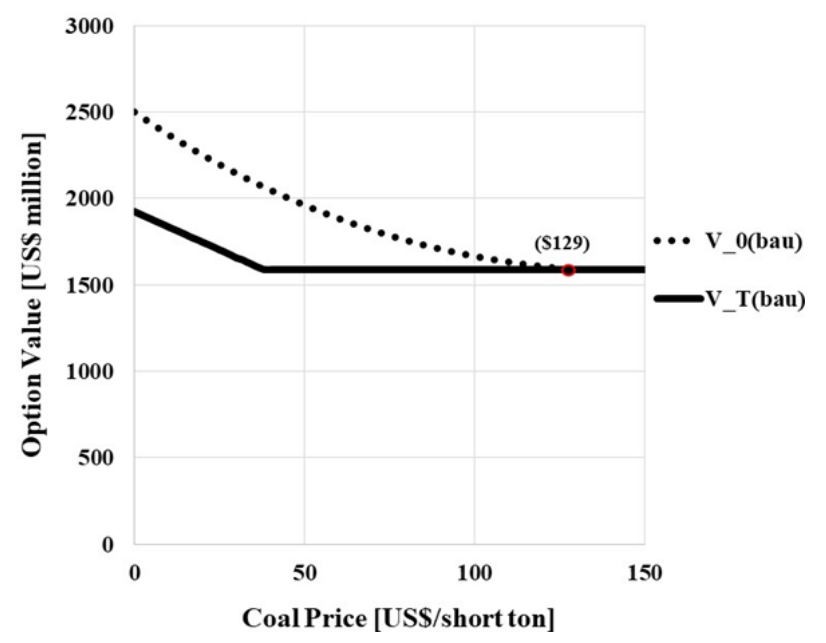

Fig .1. Option values at the business as usual scenario

\section{- Growth rate of renewable energy investment scenario}

This scenario describes an accelerated growth of investment in renewable energy sources. While the country is aiming to increase the current share of energy generation from renewables from $25 \%$ to $60 \%$ by 2030 at $4 \%$ annual growth rate [5], this goal seems unattainable as the country's electricity demand is increasing at a faster rate than renewable investments [4]. This scenario examines how changing the rate of growth in renewable energy investment affects the option values and trigger prices.

The results of dynamic optimization at various growth rates are shown in Figure 2. It can be observed that option value curves shift upwards. This implies that increasing investment in renewables incurs higher returns from economies of scale. Doubling of wind farms could result in price reductions as the costs can be spread over large production of electricity [23][25]. It can be noticed that the trigger prices of coal have also decreased from US $\$ 129 /$ short ton in the BAU scenario, to US $\$ 120$, US $\$ 113$, and US $\$ 105$ at
$4 \%, 6 \%$, and $8 \%$ growth rates. Finally, the value of waiting to invest varies from -US $\$ 105.4 \mathrm{M}$ at BAU scenario, to -US $\$ 139.5 \mathrm{M}$ at $4 \%$ growth, -US $\$ 146 \mathrm{M}$ at $6 \%$, and - US $\$ 153.7 \mathrm{M}$ at $8 \%$ growth rates. These results suggest that accelerating the current growth rate from business as usual prevents potential losses from waiting to invest in renewables.

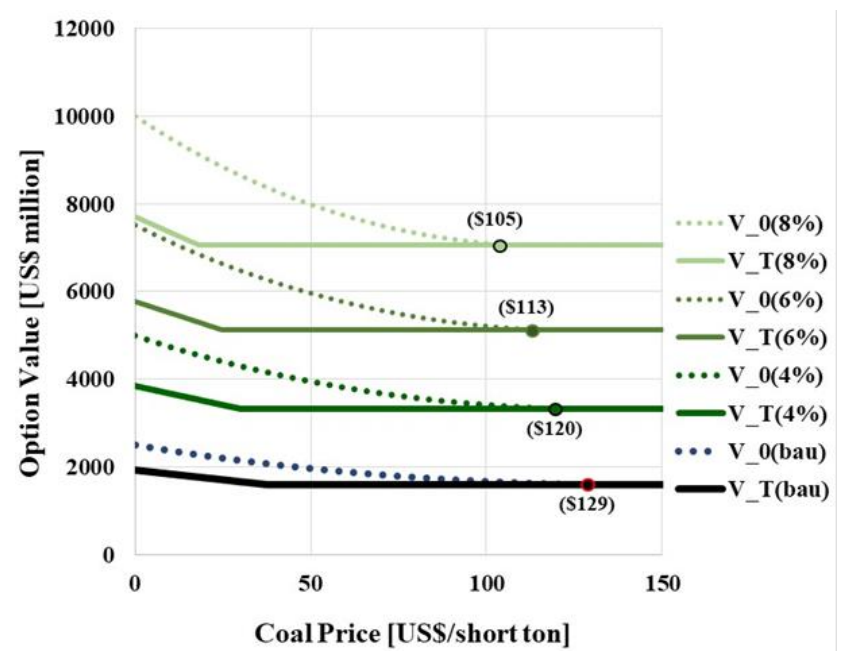

Fig .2. Option values at different rates of renewable energy investment

\section{- Price of electricity from renewable energy}

In this scenario, the effect of changing electricity prices from renewables on option values and trigger prices is analyzed. Currently, the Philippines is one of the countries with the highest electricity rates in the Asia-Pacific region. Compared with neighboring countries including Thailand, Malaysia, South Korea, Taiwan, and Indonesia, the prices are lower as the government subsidized the cost through fuel subsidy, cash grants, additional debt, and deferred expenditures. In the Philippines, electricity prices are higher due to no government subsidy, fully costreflective, imported fuel-dependent, and heavy taxes across the supply chain [26], [27]. By changing the value broadly, this scenario presents how potential government actions regarding electricity prices affect investment conditions in renewable energy.

Figure 3 illustrates the optimization outcomes with varying electricity prices. The result shows an upward shift of option values at higher electricity prices. This result is expected as higher price increases the revenues and the net present value of electricity generation from renewable energy. On the other hand, the result shows the inverse relationship of electricity prices and trigger prices from 
US $\$ 129 / \mathrm{MWh}$ in BAU to US $\$ 100 / \mathrm{MWh}$ at $10 \%$ higher and US $\$ 159 / \mathrm{MWh}$ at $10 \%$ lower electricity price. The values of waiting to invest also show a similar trend from -US\$105.4M at BAU to -US\$25.9M at higher and -US\$241.6M at lower electricity price. This implies that setting the price of electricity generated from renewables higher than current tariff provides a better environment for renewable energy investments. Nevertheless, this study also considers the possibility that extensive electricity generation from renewable energy sources has significant impact on the electricity prices as stated in previous literatures [28-30].

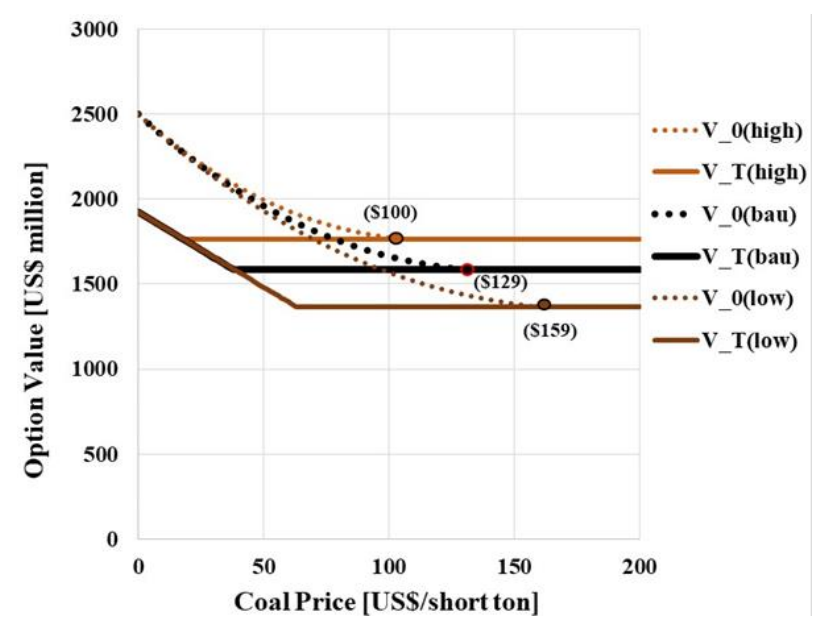

Fig .3. Option values at various electricity prices from renewable sources

\section{- Investment cost scenario}

This scenario describes how decline in overnight cost affects investment in renewables. In the recent years, growth in renewable energy investments is driven by several factors including the improving costcompetitiveness of renewable technologies, policy initiatives, better access to financing, growing demand for energy, and energy security and environmental concerns [2], [31] This scenario focuses on the effect of renewable energy cost on investment option values and trigger prices of coal for shifting technologies.

Figure 4 shows the dynamics of option values at various investment cost scenarios. The result shows an upward shift in the option value curves. This outcome is evident as lower investment cost incurs higher net present value for renewable energy,leading to higher option values. The trigger prices decrease from US $\$ 129$ in BAU to US $\$ 124$, US $\$ 119$, and
US $\$ 114$ at $5 \%, 10 \%$, and $10 \%$ cost reduction. The value of waiting also decreases from -US\$105.4M in BAU to -US $\$ 86.5 \mathrm{M}$, -US $\$ 68.6 \mathrm{M}$, and -US\$52.2M, respectively. This result confirms the rapid growth in investment as caused by the sharp decline in renewable technology costs.

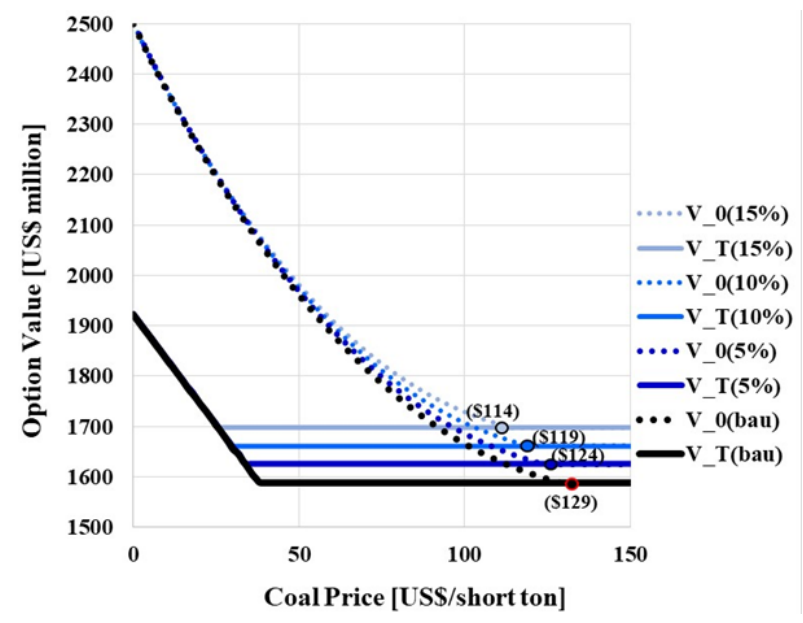

Fig .4. Option values at different decline trends of renewable investment cost

\section{- Externality scenario}

The last scenario discusses the effect of carbon prices for electricity generation from coal. Currently, there are no carbon prices in the Philippines. This study evaluates the effect of imposing carbon tax as proposed in previous literatures [32]-[34]. As shown in Figure 5, the option values and trigger prices decrease with the addition of externality cost. This result is anticipated as additional cost decreases the value of electricity generation from coal. It can also be noted that the trigger price is lower than the current price of coal equal to US $\$ 93 /$ short ton (year 2006). This implies that investing in renewables is a better option than continuing to use coal if carbon tax is imposed. Furthermore, with carbon tax, the demand for carbon-intensive inputs, including coal and oil, will decrease, while less carbon- and carbon free energy inputs eventually increase. This finally supports the research aim of analyzing renewables as a cleaner and more sustainable source of energy and a better alternative to coal. 


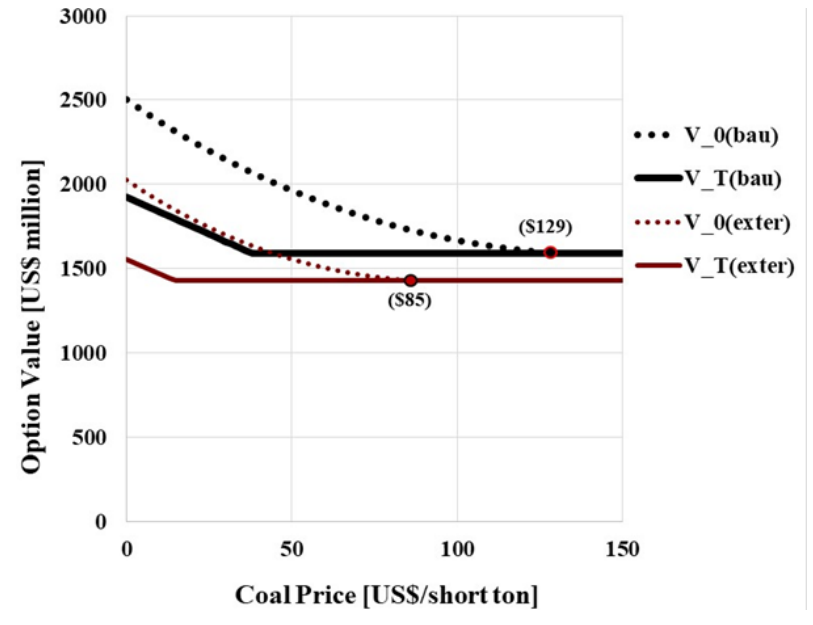

Fig .5. Option values with externality cost for using coal

\section{CONCLUSION}

This study presented various investment scenarios that represent energy switching decisions that apply to developing countries. By taking the case of the Philippines, this study employed real options approach to evaluate the maximized option values of investing in renewables, value of delaying investment, and trigger prices of coal for shifting technologies from coal to renewable sources. While numerous studies applied this approach to analyze renewable energy investments, this study expanded the existing body of research by considering a multi-period investment and taking account of uncertainties in input fuel prices, renewable technology cost, growth of investment in renewables, and externality cost for using coal.

The analyses conclude that renewable energy is a better option than continuing to use coal for electricity generation in the Philippines. Delaying the investment in renewables may lead to possible welfare losses. Shifting from fossil-based to renewable sources is very timely as the costs of renewable technologies have decreased immensely throughout the years and expected to continuously fall. To support investments in renewable energy, the government must set higher FIT rates than business as usual and impose carbon tax for using carbon-intensive fuels. Further, the growth in investment in renewables should be increased to meet the country's goal of $60 \%$ energy generation from renewable sources and decrease its dependence on imported fossil fuels.

While this study compared coal and renewables, particularly wind energy, for electricity generation, future studies may also analyze other sustainable energy sources including hydropower, solar, geothermal, biomass, tidal/ocean, and other technologies designed to improve energy efficiency. Further, environmental uncertainty, such as climate variability and weather disturbances, that affects energy generation may also be included to further capture investment scenarios relevant to climate change policy.

\section{REFERENCES}

[1] EIA. (2017b). International energy outlook 2017 table: World total energy consumption by region and fuel. Energy Information Administration. Available:

https://www.eia.gov/outlooks/aeo/data/browser/\#/ ?id=2-IEO2017 [20 Aug., 2017].

[2] FS-UNEP.( 2017). "Global trends in renewable energy investment 2017." Frankfurt School United Nations Environment Program (FS-UNEP) for Climate Change and Sustainable Energy Finance. Available: http://fs-unepcentre.org/sites/default/files/publications/globaltre ndsinrenewableenergyinvestment2017.pdf [20 Aug., 2017].

[3] BNEF. "New energy outlook 2016: Powering a Changing World." Bloomberg New Energy Finance. Available: https://about.bnef.com/newenergy-outlook/ [20 Aug., 2017].

[4] DOE, 2016. 2015 Philippine Power Statistics. Department of Energy, Philippines. Available: https://www.doe.gov.ph/sites/default/files/pdf/ener gy_statistics/power_statistics_2015_summary.pdf [16 Aug., 2017].

[5] DOE. (2012). Philippine Energy Plan 2012-2030. Department of Energy, Philippines. Available: https://www.doe.gov.ph/sites/default/files/pdf/pep/ 2012-2030_pep.pdf [16 Aug., 2017].

[6] IRENA. (2017). Renewables Readiness Assessment: The Philippines. International Renewable Energy Agency. Available: http://www.irena.org/DocumentDownloads/Publica tions/IRENA_RRA_Philippines_2017.pdf [04 Nov., 2017].

[7] L. Santos, I. Soares, C. Mendes and P. Ferreira. „Real options versus traditional methods to 
assess renewable energy projects." Renewable Energy, vol. 68, pp. 588-594, 2014. https://doi.org/10.1016/j.renene.2014.01.038

[8] M.A. Brach. Real options in practice New Jersey: John Wiley \& Sons, Inc. Hoboken, 2003.

[9] G. Kumbaroğlu, R. Madlener and M. Demirel. . "A real options evaluation model for the diffusion prospects of new renewable power generation technologies." Energy Econ, vol, 30, pp. 18821908, 2008 https://doi.org/10.1016/j.eneco.2006.10.009

[10] M.M. Zhang, P. Zhou and D.Q. Zhou. "A real options model for renewable energy investment with application to solar photovoltaic power generation in China." Energy Economics, vol. 59, pp. 213-226, 2016. https://doi.org/10.1016/j.eneco.2016.07.028

[11]K. Kim, H. Park and K. Kim. "Real options analysis for renewable energy investment decisions in developing countries." Renewable and Sustainable Energy Reviews, vol. 75, pp. 918-926, 2017 https://doi.org/10.1016/j.rser.2016.11.073

[12] L. Kitzing, N. Juul, N. Drud and T.K. Boomsma. "A real options approach to analyse wind energy investments under different support schemes." Applied Energy, vol. 188, pp. 83-96, 2017. https://doi.org/10.1016/j.apenergy.2016.11.104

[13]L. Tian, et. al.. "The valuation of photovoltaic power generation under carbon market linkage based on real options." Applied Energy, vol. 201, pp. 354-362, 2016. https://doi.org/10.1016/j.apenergy.2016.12.092

[14]I. Ritzenhofen and S. Spinler. „Optimal design of feed-in tariffs to stimulate renewable energy investments under regulatory uncertainty - A real options analysis." Energy Economics, vol. 53, pp. 76-89, 2016. https://doi.org/10.1016/j.eneco.2014.12.008

[15]A.K. Dixit and R.S. Pindyck. Investment under Uncertainty. New Jersey: Princeton University Press, 1994.
[16] O. Tietjen, M. Pahle and S. Fuss. "Investment risks in power generation: A comparison of fossil fuel and renewable energy dominated markets." Energy Economics, vol. 58, pp.174-185, 2016. https://doi.org/10.1016/j.eneco.2016.07.005

[17]X. Wang and L. Du . „Study on carbon capture and storage (CCS) investment decision-making based on real options for China's coal-fired power plants." Journal of Cleaner Production, vol. 112 (5), pp. 4123-4131, 2016. https://doi.org/10.1016/j.jclepro.2015.07.112

[18]H. Xian, G. Colson, B. Mei and M.E. Wetzstein. "Co-firing coal with wood pellets for US electricity generation: A real options analysis." Energy Policy, vol. 81, pp.106-116, 2015. https://doi.org/10.1016/j.enpol.2015.02.026

[19] N. Detert and K. Kotani. "A real options approach to energy investments in Mongolia." Energy Policy, vol. 56, pp. 136-150, 2013. https://doi.org/10.1016/j.enpol.2012.12.003

[20]M. Insley. "A real options approach to the valuation of a forestry investment." Journal of Environmental Economics and Management, vol. 44 (3), pp. 471-492, 2002. https://doi.org/10.1006/jeem.2001.1209

[21] G.A. Davis and R.D. Cairns. "Good timing: The economics of optimal stopping." Journal of Economic Dynamics and Control, vol. 36(2), pp.255-265, 2012. https://doi.org/10.1016/j.jedc.2011.09.008

[22] EIA. Levelized Cost and Levelized Avoided Cost of New Generation Resources in the Annual Energy Outlook 2017. Energy Information Administration. Available: https://www.eia.gov/outlooks/aeo/pdf/electricity_g eneration.pdf [16 Aug., 2017].

[23] H. Dai, X. Xie, Y. Xie, J. Liu and T. Masui. "Green growth: The economic impacts of large-scale renewable energy development in China." Applied Energy, vol. 162, pp. 435-449, 2016. https://doi.org/10.1016/j.apenergy.2015.10.049 
[24]Y. Qui and L.D. Anadon. "The price of wind power in China during its expansion: Technology adoption, learning-by-doing, economies of scale, and manufacturing localization." Energy Economics, vol. 34(3), pp.772-785, 2012. https://doi.org/10.1016/j.eneco.2011.06.008

[25]M. Jungunger, A. Faaij and W.C.Turkenburg. "Global experience curves for wind farms." Energy Policy, vol. 33(2), pp. 113-150, 2005. https://doi.org/10.1016/\$0301-4215(03)00205-2

[26] L. Fernandez.(2015). "Power prices: Where we are and how do we reduce the bill." Philippines' Department of Trade and Industry (DTI). Available: $\quad$ http://industry.gov.ph/wpcontent/uploads/2015/08/Power-Prices-WhereWe-Are-and-How-Can-We-Reduce-Our-Bill-byLawrence-Fernandez-MERALCO1.pdf [20 Aug., 2017].

[27] IEC. (2016). Regional/Global Comparison of Retail Electricity Tariffs. International Energy Consultants. Available: http://corporatedownloadablestips.s3.amazonaws.com/1478573661.68b4d11ba 9cb3ccb30e91c6edd66b6c9.pdf [20 Aug., 2017].

[28] J.C. Ketterer. "The impact of wind power generation on the electricity price in Germany." Energy Economics, vol. 44, pp. 270-280, 2014. https://doi.org/10.1016/j.eneco.2014.04.003

[29] T. Jonsson, P. Pinson and H. Madsen. "On the market impact of wind energy forecasts." Energy Economics, vol. 32(2), pp. 313-320, 2010. https://doi.org/10.1016/j.eneco.2009.10.018

[30] L. Gelabert, X. Labandeira and P. Linares. "An expost analysis of the effect of renewables and cogeneration on Spanish electricity prices." Energy Economics, vol. 33(1), pp. S59-S65, 2011. https://doi.org/10.1016/j.eneco.2011.07.027
[31] REN21. (2016). "Renewables 2016 global status report." Renewable Energy Network Policy for the 21st Century. Available: http://www.ren21.net/wpcontent/uploads/2016/05/GSR_2016_Full_Report _lowres.pdf [16 Aug., 2017].

[32] H. Meller and J. Marquardt. (2013). "Renewable energy in the Philippines: Costly or competitive? Facts and explanations on the price of renewable energies for electricity production." Deutsche Gesellschaft für Internationale Zusammenarbeit (GIZ) GmbH. Available: https://www.giz.de/en/downloads/giz2013-endesk-study-costs-renewable-energyphilippines.pdf [20 Aug., 2017].

[33] D. Burtraw and A. Krupnick.(2012). "The true cost of electric power: an inventory of methodologies to support future decision-making in comparing the cost and competitiveness of electricity generation technologies." Renewable Energy Network Policy for the 21st Century (REN21). Available:

http://www.ren21.net/Portals/0/documents/Resour ces/RFF-Rpt-

BurtrawKrupnick.TrueCosts_Summary_web.pdf [18 Aug., 2017].

[34] H. Cabalu, P. Koshy, E. Corong, U. E. Rodriguez and B. A. Endrigad.(2015). "Modelling the impact of energy policies on the Philippine economy: Carbon tax, energy efficiency, and changes in the energy mix." Economic Analysis and Policy vol, 48, pp. 222-237. https://doi.org/10.1016/j.eap.2015.11.014 